Article

\title{
Reactions of Recombinant Neuronal Nitric Oxide Synthase with Redox Cycling Xenobiotics: A Mechanistic Study
}

\author{
Mindaugas Lesanavičius ${ }^{1}$ (D), Jean-Luc Boucher ${ }^{2}$ and Narimantas Čènas ${ }^{1, *}$ \\ 1 Department of Xenobiotics Biochemistry, Institute of Biochemistry of Vilnius University, Sauletekio 7, \\ LT-10257 Vilnius, Lithuania; mindaugas.lesanavicius@gmc.vu.lt \\ 2 Laboratoire de Chimie \& Biochimie Pharmacologiques et Toxicologiques, CNRS UMR 8601, \\ Université Paris Descartes, 45 rue de Saints Pères, CEDEX 06, 75270 Paris, France; \\ jean-luc.boucher@parisdescartes.fr \\ * Correspondence: narimantas.cenas@bchi.vu.lt; Tel.: +370-223-4392
}

check for updates

Citation: Lesanavičius, M.; Boucher, J.-L.; Čènas, N. Reactions of Recombinant Neuronal Nitric Oxide Synthase with Redox Cycling Xenobiotics: A Mechanistic Study. Int J. Mol. Sci. 2022, 23, 980. https:// doi.org/10.3390/ijms23020980

Academic Editor: Christo Z. Christov

Received: 28 November 2021

Accepted: 14 January 2022

Published: 17 January 2022

Publisher's Note: MDPI stays neutral with regard to jurisdictional claims in published maps and institutional affiliations.

Copyright: (C) 2022 by the authors. Licensee MDPI, Basel, Switzerland. This article is an open access article distributed under the terms and conditions of the Creative Commons Attribution (CC BY) license (https:// creativecommons.org/licenses/by/ $4.0 /)$.

\begin{abstract}
Neuronal nitric oxide synthase (nNOS) catalyzes single-electron reduction of quinones (Q), nitroaromatic compounds $\left(\mathrm{ArNO}_{2}\right)$ and aromatic $N$-oxides $(\mathrm{ArN} \rightarrow \mathrm{O})$, and is partly responsible for their oxidative stress-type cytotoxicity. In order to expand a limited knowledge on the enzymatic mechanisms of these processes, we aimed to disclose the specific features of $\mathrm{nNOS}$ in the reduction of such xenobiotics. In the absence or presence of calmodulin (CAM), the reactivity of $Q$ and ArN $\rightarrow \mathrm{O}$ increases with their single-electron reduction midpoint potential $\left(E^{1}{ }_{7}\right) . \mathrm{ArNO}_{2}$ form a series with lower reactivity. The calculations according to an "outer-sphere" electron transfer model show that the binding of CAM decreases the electron transfer distance from $\mathrm{FMNH}_{2}$ to quinone by $1-2 \AA$. The effects of ionic strength point to the interaction of oxidants with a negatively charged protein domain close to FMN, and to an increase in accessibility of the active center induced by high ionic strength. The multiple turnover experiments of nNOS show that, in parallel with reduced FAD-FMN, duroquinone reoxidizes the reduced heme, in particular its $\mathrm{Fe}^{2+}-\mathrm{NO}$ form. This finding may help to design the heme-targeted bioreductively activated agents and contribute to the understanding of the role of P-450-type heme proteins in the bioreduction of quinones and other prooxidant xenobiotics.
\end{abstract}

Keywords: nitric oxide synthase; quinones; nitroaromatic compounds; aromatic $\mathrm{N}$-oxides; reduction mechanism; oxidative stress

\section{Introduction}

Nitric oxide (NO) is produced physiologically to perform a range of signaling functions and as an immune response agent [1]. The mammalian NO synthases (NOS, EC 1.14.13.39) are dimeric flavohemoproteins that catalyze the conversion of $L$-arginine to $N O$. and citrulline at the expense of NADPH. The monomer of NOS consists of a heme domain with a tetrahydrobiopterin $\left(\mathrm{H}_{4} \mathrm{~B}\right)$ bound at its $N$-terminus, and a FAD- and FMN-containing reductase domain at its $C$-terminus. The reductase and oxygenase domains are linked by a calmodulin (CAM)-binding sequence ([2,3], and references therein). The FAD-FMN domain of NOS is highly similar to that of microsomal NADPH:cytochrome P-450 reductase (P-450R, EC 1.6.2.4) [4-6]. The redox equivalents are transferred along the pathway NADPH $\rightarrow$ FAD $\rightarrow$ FMN $\rightarrow$ heme (tetrahydrobiopterin), and the FAD-FMN domain of NOS cycles mainly between one- and three-electron reduced states in the turnover [7-10]. The multistep NO. synthesis by NOS involves the formation of several heme $\mathrm{Fe}^{3+} / \mathrm{Fe}^{2+}$ complexes (Scheme 1) and electron exchange between the heme and $\mathrm{H}_{4} \mathrm{~B}[2,11]$. Importantly, only part of the NO. synthesized by NOS is released from the enzyme, because a significant fraction of its $\mathrm{Fe}^{2+}-\mathrm{NO}$ complex participates in the futile redox cycling which is not accompanied by NO- dissociation (Scheme 1) [12-14]. The catalysis of NOS involves the movement of FMNcontaining domain and is regulated in a complex way by the binding of CAM, NADP(H), and the interdomain electrostatic interaction ([6-9,15-17] and references therein). 


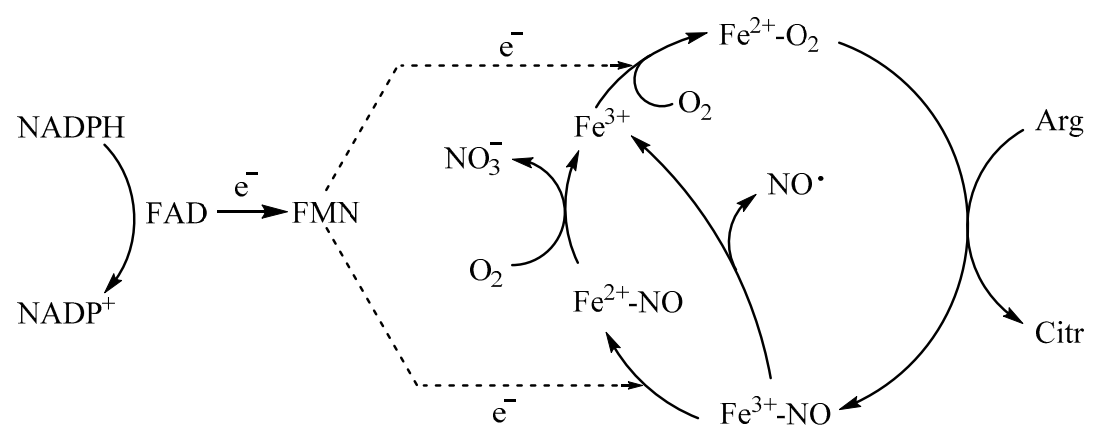

Scheme 1. A simplified scheme of catalysis of nNOS (adapted from $[2,13,14]$ ).

Like other flavoenzymes dehydrogenases-electron transferases, NOS reduces anticancer quinones $(\mathrm{Q})$ and aromatic $\mathrm{N}$-oxides $(\mathrm{ArN} \rightarrow \mathrm{O}$ ), and toxic or therapeutic nitroaromatic compounds $\left(\mathrm{ArNO}_{2}\right)$ in a single-electron way $[8,10,18-22]$. The radicals of the above compounds undergo redox cycling which may contribute significantly to the oxidative stress-type cytotoxicity. In particular, the neuronal form of NOS (nNOS) is the key factor in doxorubicin-induced toxicity to neurons [23], and may be involved in the neurotoxic action of dinitrobenzenes [24]. Because nNOS is overexpressed in astrocytic tumors, it may be regarded as a potential target for anticancer agents [25]. In turn, the inducible form of NOS (iNOS) is partly responsible for the reductive activation of anticancer agents 2-nitroimidazole EF5 and benzotriazine- $N$-oxide SN30000 [26]. In this case, its contribution was lower but still comparable to that of P-450R. Additionally, the NOS-catalyzed redox cycling of $\mathrm{Q}$ and $\mathrm{ArNO}_{2}$ may inhibit the formation of $\mathrm{NO}$. because of its rapid reaction with the forming superoxide [24,27].

In spite of their importance, there exists a limited information on the mechanisms of reactions of NOS with redox cycling xenobiotics. The kinetic studies of flavin reductase domain of nNOS $[8,10]$ and the insensitivity of quinone- and nitroreductase activity of holo-nNOS to $N^{\omega}$-nitro-L-arginine $\left(\mathrm{NO}_{2}\right.$-Arg) that binds at the heme moiety lead to the conclusion that nNOS reduces the above compounds via $\mathrm{FMNH}_{2}$ and, possibly, $\mathrm{FADH}_{2}$ without the involvement of the heme $[19,20,26]$. In the absence of CAM, i.e., under the impeded electron transfer between the enzyme redox cofactors $[16,17]$, nNOS shows little specificity towards the structure of quinones and nitroaromatic compounds, because their reactivity increases with their single-electron reduction midpoint potential $\left(E^{1}{ }_{7}\right)$ [22].

Extending our previous studies [22], we examined the reactions of nNOS with a number of oxidants of different structure, redox potential and electrostatic charge, with an emphasis on the specific aspects of reaction activation and regulation by the binding of $\mathrm{CAM}, \mathrm{NADP}^{+}$, and the ionic strength of solution. Apart from the more comprehensive characterization of the functions of FMN domain, our data point to a parallel involvement of the heme moiety, in particular its $\mathrm{Fe}^{2+}-\mathrm{NO}$ complex, in the reduction of xenobiotics.

\section{Results}

\subsection{Steady-State Kinetics and Substrate Specificity of nNOS}

Previously we found that in the absence of CAM, quinones and nitroaromatic compounds form separate series of oxidants whose reactivity $\left(\log k_{\text {cat }} / K_{\mathrm{m}}\right.$, where $k_{\text {cat }} / K_{\mathrm{m}}$ is bimolecular reaction rate constant) increases with their $E^{1}{ }_{7}$ [22]. The reactions were analyzed using an "outer-sphere" electron-transfer model, which describes an electron transfer with weak electronic coupling between the reactants ([28], and references therein), and the absence of pronounced structure specificity. In the simplest form, the rate constants of single-electron transfer between reagents $\left(k_{12}\right)$ depends on the electron self-exchange rate constants of reagents $\left(k_{11}\right.$ and $\left.k_{22}\right)$ and equilibrium constant of reaction $(K)\left(\log K=\Delta E^{1}\right.$ (V) $/ 0.059$, where $\Delta E^{1}$ is the difference in the standard single-electron transfer potentials of reactants):

$$
k_{12}=\left(k_{11} \times k_{22} \times K \times f\right)^{1 / 2}
$$


and

$$
\log f=(\log K)^{2} / 4 \log \left(k_{11} \times k_{22} / Z^{2}\right)
$$

where $Z$ is a frequency factor $\left(10^{11} \mathrm{M}^{-1} \mathrm{~s}^{-1}\right)$. According to Equations (1) and (2), in the reaction of electron donor with a series of homologous electron acceptors $\left(k_{22}=\right.$ constant $)$, $k_{12}$ will exhibit parabolic (square) dependence on $\Delta E^{1}$ with a slope $\Delta \log k / \Delta \Delta E^{1}=8.45 \mathrm{~V}^{-1}$ at $\Delta E^{1}= \pm 0.15 \mathrm{~V}$. At $\Delta E^{1}=0, k_{12}=\left(k_{11} \times k_{22}\right)^{1 / 2}$. Thus, the lower reactivity of $\mathrm{ArNO}_{2}$ was attributed to their $k_{22} \sim 10^{6} \mathrm{M}^{-1} \mathrm{~S}^{-1}$ [29], which is much lower than that of quinones, $10^{8} \mathrm{M}^{-1} \mathrm{~s}^{-1}[30]$.

In this study, we examined the reactions of nNOS with a number of oxidants possessing a broad range of $E^{1}{ }_{7}$ values and different electrostatic charge, including the anticancer agents such as the derivatives of tirapazamine (1-6) and dinitrobenzamide CB-1954 (24), and toxic environment pollutants tetryl (19) and 2,4,6-trinitrotoluene (20) (Table 1) $\left([8,9,18-22]\right.$, and references therein). Because the $K_{\mathrm{m}}$ for NADPH in nNOS-catalyzed reactions is in the micromolar range [31], the measurements were performed at a single saturating concentration of NADPH, $50 \mu \mathrm{M}$. The maximal reduction rate constants (reaction turnover numbers, $k_{\mathrm{cat}}$ ) of these electron acceptors, and their $k_{\mathrm{cat}} / K_{\mathrm{m}}$ values are given in Table 1.

Table 1. Steady-state rate constants of the reduction of nonphysiological electron acceptors by NADPH catalyzed by nNOS. [NADPH] $=50 \mu \mathrm{M}, 0.1 \mathrm{M}$ Tris/HCl $+1 \mathrm{mM}$ EDTA $+100 \mathrm{mM} \mathrm{NaCl}$, $\mathrm{pH} 7.0,25^{\circ} \mathrm{C} ; 10 \mu \mathrm{g} / \mathrm{mL}$ calmodulin (CAM) and $1.0 \mathrm{mM} \mathrm{CaCl}_{2}$, where applicable.

\begin{tabular}{|c|c|c|c|c|c|c|}
\hline \multirow{2}{*}{ No. } & \multirow{2}{*}{ Compound } & \multirow{2}{*}{$E^{1}{ }_{7}(\mathrm{~V})[32,33]$} & \multicolumn{2}{|c|}{- CAM } & \multicolumn{2}{|c|}{ +CAM } \\
\hline & & & $k_{\text {cat }}\left(\mathrm{s}^{-1}\right)$ & $k_{\mathrm{cat}} / K_{\mathrm{m}}\left(\mathrm{M}^{-1} \mathbf{s}^{-1}\right)$ & $k_{\text {cat }}\left(\mathrm{s}^{-1}\right)$ & $k_{\text {cat }} / K_{\mathrm{m}}\left(\mathrm{M}^{-1} \mathrm{~s}^{-1}\right)$ \\
\hline \multicolumn{7}{|c|}{ Aromatic $N$-oxides } \\
\hline 1. & 7- $\mathrm{CF}_{3}$-tirapazamine & -0.345 & $3.98 \pm 0.38$ & $9.9 \pm 1.2 \times 10^{3}$ & $16.3 \pm 1.8$ & $2.5 \pm 0.2 \times 10^{4}$ \\
\hline 2. & 7-Cl-tirapazamine & -0.400 & $0.84 \pm 0.08$ & $1.4 \pm 0.1 \times 10^{4}$ & $14.8 \pm 1.7$ & $4.0 \pm 0.6 \times 10^{5}$ \\
\hline 3. & 7-F-tirapazamine & -0.400 & $2.84 \pm 0.23$ & $1.2 \pm 0.1 \times 10^{4}$ & $11.1 \pm 1.1$ & $1.4 \pm 0.1 \times 10^{5}$ \\
\hline 4. & $\begin{array}{l}\text { 3-Amino-1,2,4-benzotriazine-1,4- } \\
\text { dioxide (tirapazamine) }\end{array}$ & -0.456 & $0.69 \pm 0.09$ & $1.1 \pm 0.1 \times 10^{3}$ & $5.22 \pm 0.66$ & $3.9 \pm 0.2 \times 10^{4}$ \\
\hline 5. & 7- $\mathrm{CH}_{3}$-tirapazamine & -0.474 & $0.60 \pm 0.09$ & $1.3 \pm 0.2 \times 10^{3}$ & ND & ND \\
\hline 6. & 7- $\mathrm{C}_{2} \mathrm{H}_{5} \mathrm{O}$-tirapazamine & -0.494 & $0.67 \pm 0.09$ & $2.2 \pm 0.2 \times 10^{3}$ & $2.94 \pm 0.71$ & $2.6 \pm 0.2 \times 10^{4}$ \\
\hline \multicolumn{7}{|c|}{ Quinones } \\
\hline 7. & 1,4-Benzoquinone & 0.090 & $12.9 \pm 1.5$ & $5.1 \pm 0.7 \times 10^{5}$ & $61.4 \pm 7.2$ & $1.3 \pm 0.2 \times 10^{6}$ \\
\hline 8. & 2,6-( $\left(\mathrm{CH}_{3}\right)_{2}-1,4$-benzoquinone & -0.080 & $6.84 \pm 0.42$ & $1.4 \pm 0.2 \times 10^{5}$ & $55.8 \pm 3.4$ & $1.0 \pm 0.1 \times 10^{6}$ \\
\hline 9. & 5-OH-1,4-naphthoquinone & -0.090 & $23.3 \pm 1.9$ & $2.8 \pm 0.4 \times 10^{6}$ & $42.2 \pm 1.8$ & $7.0 \pm 0.6 \times 10^{6}$ \\
\hline 10. & 5,8-(OH $)_{2}-1,4$-naphthoquinone & -0.110 & $11.5 \pm 1.2$ & $1.8 \pm 0.2 \times 10^{6}$ & $24.7 \pm 4.8$ & $5.0 \pm 0.5 \times 10^{7}$ \\
\hline 11. & 1,4-Naphthoquinone & -0.150 & $7.98 \pm 0.40$ & $3.4 \pm 0.7 \times 10^{5}$ & $38.2 \pm 2.6$ & $2.4 \pm 0.3 \times 10^{6}$ \\
\hline 12. & 2- $\mathrm{CH}_{3}-1,4$-naphthoquinone & -0.200 & $8.50 \pm 0.80$ & $1.6 \pm 0.3 \times 10^{5}$ & $37.9 \pm 2.5$ & $1.3 \pm 0.2 \times 10^{6}$ \\
\hline 13. & $\begin{array}{c}\left(\mathrm{CH}_{3}\right)_{4}-1,4 \text {-benzoquinone } \\
\text { (duroquinone) }\end{array}$ & -0.260 & $4.71 \pm 0.34$ & $8.0 \pm 1.0 \times 10^{4}$ & $\begin{array}{l}115.0 \pm 7.0 \\
112.2 \pm 4.3^{\mathrm{a}} \\
84.3 \pm 5.1^{\mathrm{b}}\end{array}$ & $\begin{array}{l}2.1 \pm 0.2 \times 10^{6} \\
1.2 \pm 0.1 \times 10^{6 a} \\
1.1 \pm 0.1 \times 10^{6 b}\end{array}$ \\
\hline 14. & 2-OH-1,4-naphthoquinone & -0.410 & $0.39 \pm 0.05$ & $4.4 \pm 0.4 \times 10^{3}$ & $3.11 \pm 0.35$ & $4.0 \pm 0.3 \times 10^{4}$ \\
\hline \multicolumn{7}{|c|}{ Single electron acceptors } \\
\hline 15. & Ferricyanide & 0.410 & $30.4 \pm 3.5$ & $1.2 \pm 0.2 \times 10^{5}$ & $102.4 \pm 5.9$ & $3.3 \pm 0.3 \times 10^{6}$ \\
\hline 16. & Cytochrome $c$ & 0.250 & $9.66 \pm 0.35$ & $1.9 \pm 0.2 \times 10^{5}$ & $104.1 \pm 2.2$ & $5.3 \pm 0.3 \times 10^{6}$ \\
\hline 17. & $\mathrm{Fe}(\mathrm{EDTA})^{-}$ & 0.120 & $7.30 \pm 1.30$ & $7.0 \pm 1.0 \times 10^{3}$ & $11.0 \pm 1.2$ & $2.8 \pm 0.2 \times 10^{4}$ \\
\hline 18. & Benzylviologen & -0.354 & $6.60 \pm 0.40$ & $3.4 \pm 0.2 \times 10^{4}$ & $23.5 \pm 1.4$ & $1.7 \pm 0.1 \times 10^{5}$ \\
\hline \multicolumn{7}{|c|}{ Nitroaromatic compounds } \\
\hline 19. & $\begin{array}{l}\text { 2,4,6-Trinitrophenyl- } N \text {-methyl- } \\
\text { nitramine (tetryl) }\end{array}$ & -0.191 & ND & ND & $52.0 \pm 2.6$ & $6.8 \pm 0.5 \times 10^{6}$ \\
\hline 20. & 2,4,6-Trinitrotoluene & -0.253 & ND & ND & $46.4 \pm 5.2$ & $1.5 \pm 0.1 \times 10^{5}$ \\
\hline 21. & $o$-Dinitrobenzene & -0.287 & ND & ND & $18.9 \pm 3.0$ & $8.0 \pm 0.7 \times 10^{4}$ \\
\hline 22. & $m$-Dinitrobenzene & -0.348 & ND & ND & $10.1 \pm 0.9$ & $8.9 \pm 0.6 \times 10^{3}$ \\
\hline 23. & $p$-Nitroacetophenone & -0.355 & ND & ND & $4.67 \pm 1.40$ & $2.7 \pm 0.3 \times 10^{4}$ \\
\hline 24. & $\begin{array}{l}\text { 5-(1-Aziridinyl)-2,4-dinitro- } \\
\text { benzamide (CB-1954) }\end{array}$ & -0.385 & ND & ND & $8.83 \pm 0.80$ & $2.7 \pm 0.2 \times 10^{4}$ \\
\hline
\end{tabular}

a_-The reaction medium contains $\mathrm{H}_{4} \mathrm{~B}$ and $\mathrm{Arg}$; ${ }^{\mathrm{b}}$-The reaction medium contains $\mathrm{H}_{4} \mathrm{~B}$, Arg and $1.0 \mathrm{mM} \mathrm{NO}_{2}$ - $\mathrm{Arg}$; ND—not determined. 
First, we assessed the reactivity of a previously unexplored group of oxidants, $\mathrm{ArN} \rightarrow \mathrm{O}$, in the absence of CAM. Figure $1 \mathrm{~A}$ shows that $\log k_{\mathrm{cat}} / K_{\mathrm{m}}$ of derivatives of 3-amino-1,2,4benzotriazine-1,4-dioxide (tirapazamine), quinones and quinoidal single-electron acceptor benzylviologen, follow a common although scattered parabolic dependence on their $E^{1}{ }_{7}$ values. According to an "outer-sphere" electron-transfer model [28], this may be attributed to their similar electron self-exchange rate constants, $\sim 10^{8} \mathrm{M}^{-1} \mathrm{~s}^{-1}[30,34]$. As expected, the addition of CAM significantly, but to a different extent, increased both the $k_{\text {cat }}$ and $k_{\text {cat }} / K_{\mathrm{m}}$ values of various groups of electron acceptors (Table 1$)$. This resulted in a more scattered dependence of compound reactivity on their $E^{1}{ }_{7}$ (Figure 1B). Nevertheless, the reactivity $\mathrm{ArN} \rightarrow \mathrm{O}$ remains similar to that of quinones. $\mathrm{ArNO}_{2}$ are less reactive than $\mathrm{Q}$ (Figure $1 \mathrm{~B}$ ), like in the experiments performed in the absence of CAM [22]. The addition of $\mathrm{H}_{4} \mathrm{~B}$ decreased the rate constants of reduction of tetramethyl-1,4-benzoquinone (duroquinone) by $7-10 \%$, and the addition of $1.0 \mathrm{mM}$ dithiothreitol did not influence the reaction rate (data not shown). Importantly, the addition of $1.0 \mathrm{mM} \mathrm{NO}_{2}$-Arg decreased the $k_{\text {cat }}$ of reaction by 25\% (Table 1).
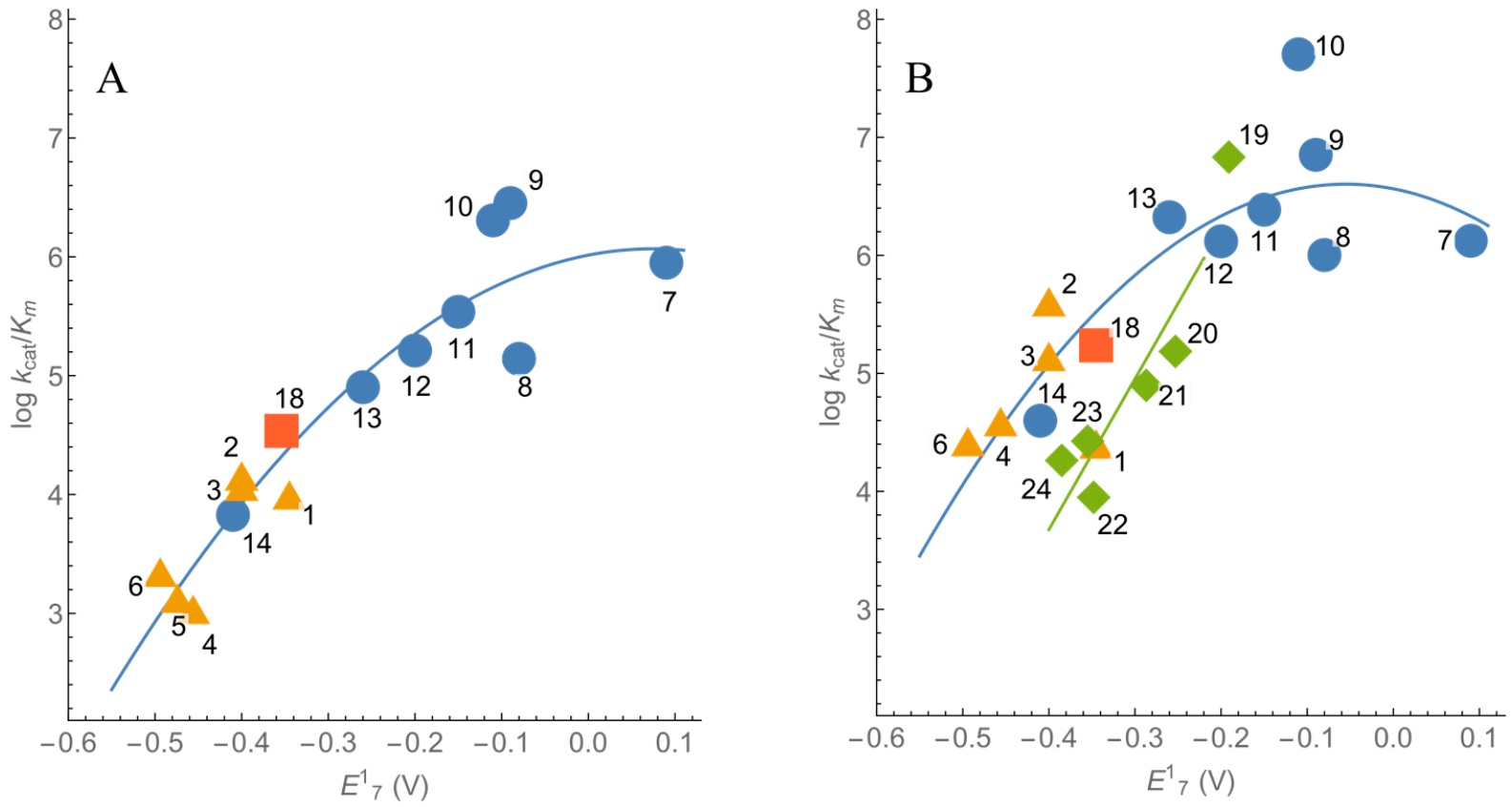

Figure 1. The dependence of the reactivity of quinones (blue disks), aromatic $N$-oxides (orange triangles), nitroaromatic compounds (green diamonds) and benzylviologen (red rectangle) on their single-electron reduction midpoint potentials $\left(E^{1}{ }_{7}\right)$ at $\mathrm{pH} 7.0$ in the absence $(\mathbf{A})$ and presence $(\mathbf{B})$ of CAM and $\mathrm{Ca}^{2+}$. The numbers of compounds are given in Table 1.

Next, we examined the effects of the ionic strength of the solution on the reactivity of electron acceptors. Electrostatic interactions play important role in the electron transfer reactions of FMN, first in the association of the FMN-binding domain with the FAD-binding domain, and, after the conformational change, in its complex formation with the heme domain [6,35-39]. However, most studies on the effects of ionic strength on the reactivity of nonphysiological oxidants were performed with their fixed concentrations, and provided limited information on the mode of their interaction with the FMN domain $[35,37,38]$.

Using varied concentrations of uncharged oxidant duroquinone, we found that its $k_{\text {cat }}$ attains the maximal value at high ionic strength (Figure 2A). Similar dependence is also characteristic for $k_{\text {cat }}$ of cytochrome $c$, benzylviologen and ferricyanide (data not shown). On the other hand, $k_{\text {cat }}$ of duroquinone attains a bell-shape dependence on the ionic strength in the presence of CAM (Figure 2A). The ionic strength also increases the $k_{\text {cat }} / K_{\mathrm{m}}$ of duroquinone, but attenuates the activating effect of CAM (Figure $2 \mathrm{~B}$ ). The data of Figure $2 \mathrm{C}$ show that $\log k_{\mathrm{cat}} / K_{\mathrm{m}}$ of negatively charged oxidants, ferricyanide and 
Fe(EDTA $)^{-}$, increases with the ionic strength of solution. The decrease of the reactivity of positively charged cytochrome $c$ and benzylviologen is less pronounced (Figure 2C). In general, these data point to the interaction of charged oxidants with the negatively charged FMN-binding domain (Figure 2C).
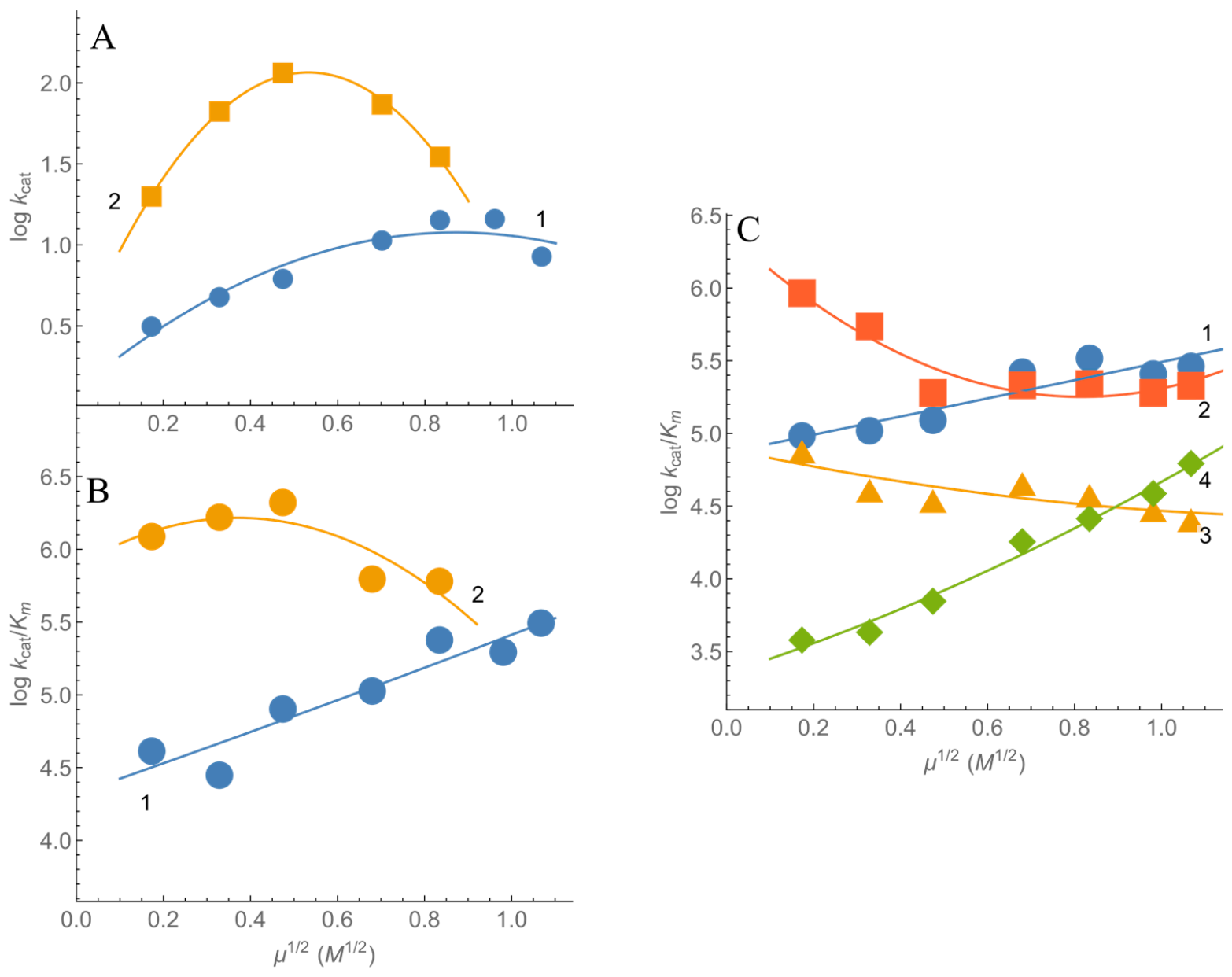

Figure 2. The effects of ionic strength on the reactivity of nNOS towards electron acceptors. (A) The dependence of $k_{\text {cat }}$ of duroquinone on the ionic strength in the absence of calmodulin (1, blue disks) and its presence (2, orange squares). (B) The dependence of $k_{\mathrm{cat}} / K_{\mathrm{m}}$ of duroquinone on the ionic strength in the absence of calmodulin (1, blue disks), and its presence (2, orange disks). (C) The dependence of $k_{\text {cat }} / K_{\mathrm{m}}$ for ferricyanide (1, blue disks), cytochrome $c\left(2\right.$, red squares), Fe(EDTA) ${ }^{-}$(3, green diamonds) and benzylviologen (4, orange triangles) on the ionic strength. $[\mathrm{NADPH}]=50 \mu \mathrm{M}$, ionic strength varied by the addition of $\mathrm{NaCl}$ to $0.03 \mathrm{M}$ Tris $/ \mathrm{HCl}$.

Another insufficiently elucidated problem in the reduction of nonphysiological oxidants by nNOS, is the character of inhibition by reaction product, $\mathrm{NADP}^{+}$, and its relationship with $\mathrm{NADP}(\mathrm{H})$-induced conformational transitions [15,31]. Figure 3A,B demonstrates typical inhibition patterns obtained at several concentrations of $\mathrm{NADP}^{+}$and its redox inactive derivative $2^{\prime}, 5^{\prime}$-ADP. At a fixed concentration of duroquinone, both compounds act as competitive inhibitors to NADPH, because they decrease $k_{\text {cat }} / K_{\mathrm{m}}$ of NADPH, but do not affect the $k_{\text {cat }}$ value of the reaction (Figure $3 \mathrm{~A}$ ). This shows that they bind at the NADPH-binding site in the oxidized enzyme form. Figure 3B shows that at a fixed concentration of NADPH, both compounds act as noncompetitive inhibitors to duroquinone, decreasing its $k_{\text {cat }} / K_{\mathrm{m}}$ and $k_{\text {cat }}$ of the reaction. 
The noncompetitive inhibition constants $\left(K_{\mathrm{i}}\right)$ were calculated according to Equation (3) at $5-6$ concentrations of $\mathrm{NADP}^{+}$or $2^{\prime}, 5^{\prime}-\mathrm{ADP}$ (data not shown):

$$
v /[\mathrm{E}]=k_{\text {cat }}[\mathrm{Q}] /\left(K_{\mathrm{m}}+[\mathrm{Q}]\right) \times\left(1+[\mathrm{I}] / K_{\mathrm{i}}\right)
$$

where $Q$ stands for oxidant and I stands for inhibitor. They were equal to $2.5 \pm 0.2 \mathrm{mM}$ for $\mathrm{NADP}^{+}$and $0.25 \pm 0.04 \mathrm{mM}$ for $2^{\prime}, 5^{\prime}$-ADP. The decrease of $k_{\text {cat(app.) }}$ in the presence of high concentrations of $\mathrm{NADP}^{+}$and $2^{\prime}, 5^{\prime}$-ADP (Figure $3 \mathrm{~B}$ ) is most probably related to an increased $K_{\mathrm{m}}$ of NADPH (Figure 3A). In this case, $50 \mu \mathrm{M}$ NADPH is no longer a saturating concentration and does not ensure the maximal reaction rate.
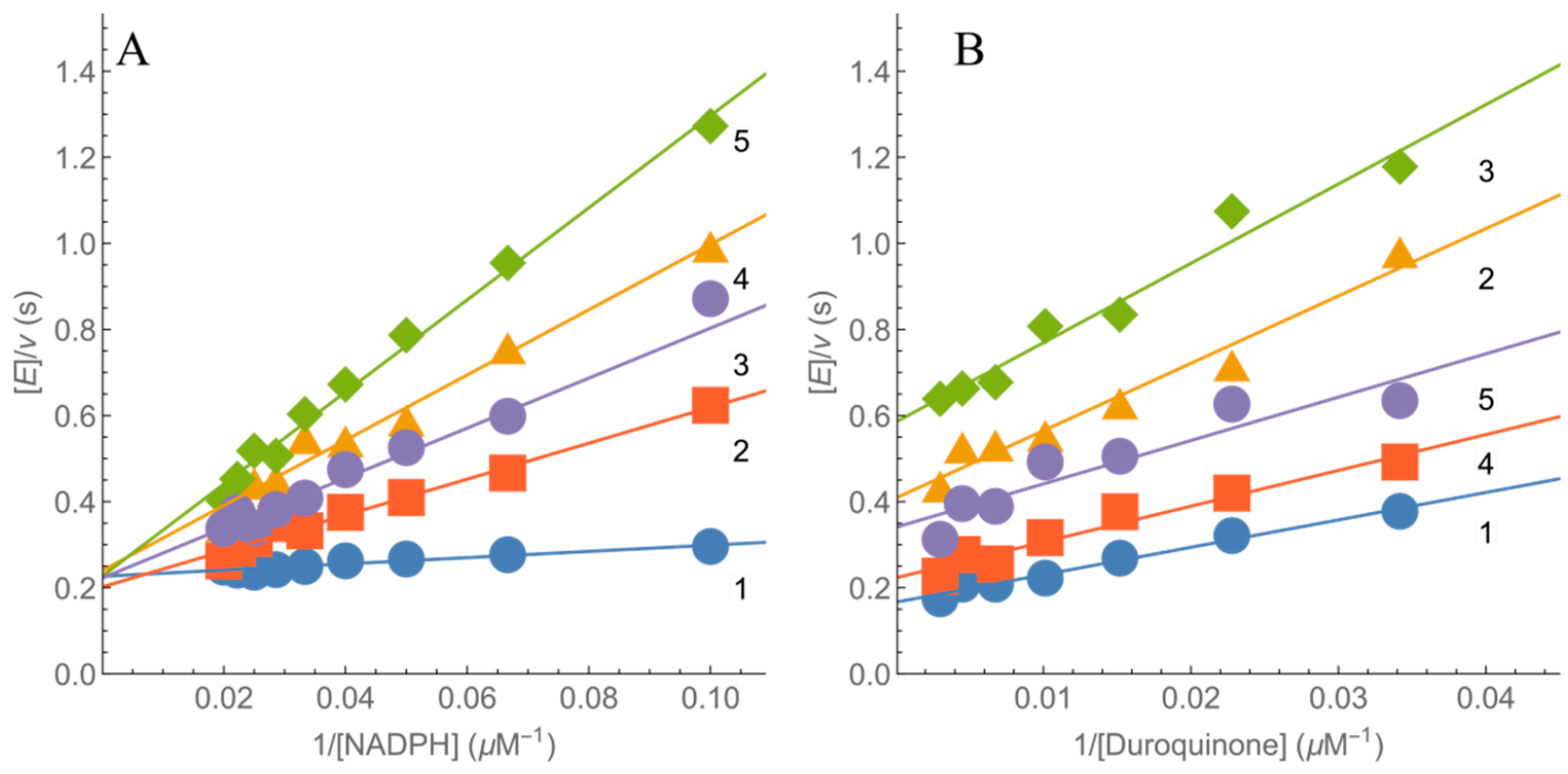

Figure 3. Inhibition of the duroquinone reductase reaction of $\mathrm{nNOS}$ by $\mathrm{NADP}^{+}$and $2^{\prime}, 5^{\prime}$-ADP. (A) Inhibition at varied NADPH concentrations in the presence of $250 \mu \mathrm{M}$ duroquinone: 1 -inhibitor is absent, 2-200 $\mu \mathrm{M} \mathrm{NADP}^{+}, 3-400 \mu \mathrm{M} \mathrm{NADP}^{+}, 4-50 \mu \mathrm{M} 2^{\prime}, 5^{\prime}$-ADP, 5-100 $\mu \mathrm{M} 2^{\prime}, 5^{\prime}$-ADP. (B) Inhibition at varied concentrations of duroquinone in the presence of $50 \mu \mathrm{M}$ NADPH: 1 -inhibitor is absent, 2-1.0 mM NADP ${ }^{+}, 3-2.0 \mathrm{mM} \mathrm{NADP}^{+}, 4-250 \mu \mathrm{M} 2^{\prime}, 5^{\prime}-\mathrm{ADP}, 5-500 \mu \mathrm{M} 2^{\prime}, 5^{\prime}-\mathrm{ADP}$. [E] is the enzyme concentration $(\mathrm{M})$, and $v$ is reaction rate $\left(\mathrm{Ms}^{-1}\right)$.

\subsection{Kinetics of $n N O S$ Oxidation under Multiple Turnover Conditions}

In order to get insight into the mechanism of nNOS reoxidation by quinones, we investigated the changes of flavin and heme absorbance during enzyme multiple turnover under aerobic conditions. The reduction of flavins and heme was monitored following their absorbance decrease at $485 \mathrm{~nm}$ (heme isosbestic point) and $397 \mathrm{~nm}$, respectively, whereas the formation of $\mathrm{Fe}^{2+}-\mathrm{NO}$ complex was monitored following the absorbance increase at $436 \mathrm{~nm}[13,14,40]$. In parallel, the oxidation of NADPH was monitored according to the absorbance decrease at $340 \mathrm{~nm}$. The data of Figure 4 show that nNOS was rapidly reduced by $\mathrm{NADPH}$ and slowly reoxidized by $\mathrm{O}_{2}$. Importantly, the amplitude of absorbance changes at $397 \mathrm{~nm}$ was comparable with those at $485 \mathrm{~nm}$, pointing to a strong contribution of flavin spectral changes. The $436 \mathrm{~nm}$ absorbance changes are opposite to those expected for $\mathrm{Fe}^{2+}-\mathrm{NO}$ formation $[13,40]$, and are attributed to FAD-FMN reduction. Following the oxidation by $\mathrm{O}_{2}$, the $485 \mathrm{~nm}, 397 \mathrm{~nm}$ and $436 \mathrm{~nm}$ absorbance does not return to an initial level, which indicates that the reduction product is stable single-electron reduced FADFMN [7-10,40]. The final drop of absorbance at $397 \mathrm{~nm}$ may be also partly caused by the oxidation of NADPH, which still weakly absorbs at this wavelength. Next, duroquinone, which does not possess absorbance in this region, was used as the electron acceptor. Its 
addition increases the enzyme reoxidation rate by more than one order of magnitude and decreases the amplitude of absorbance changes (Figure 4A-D).
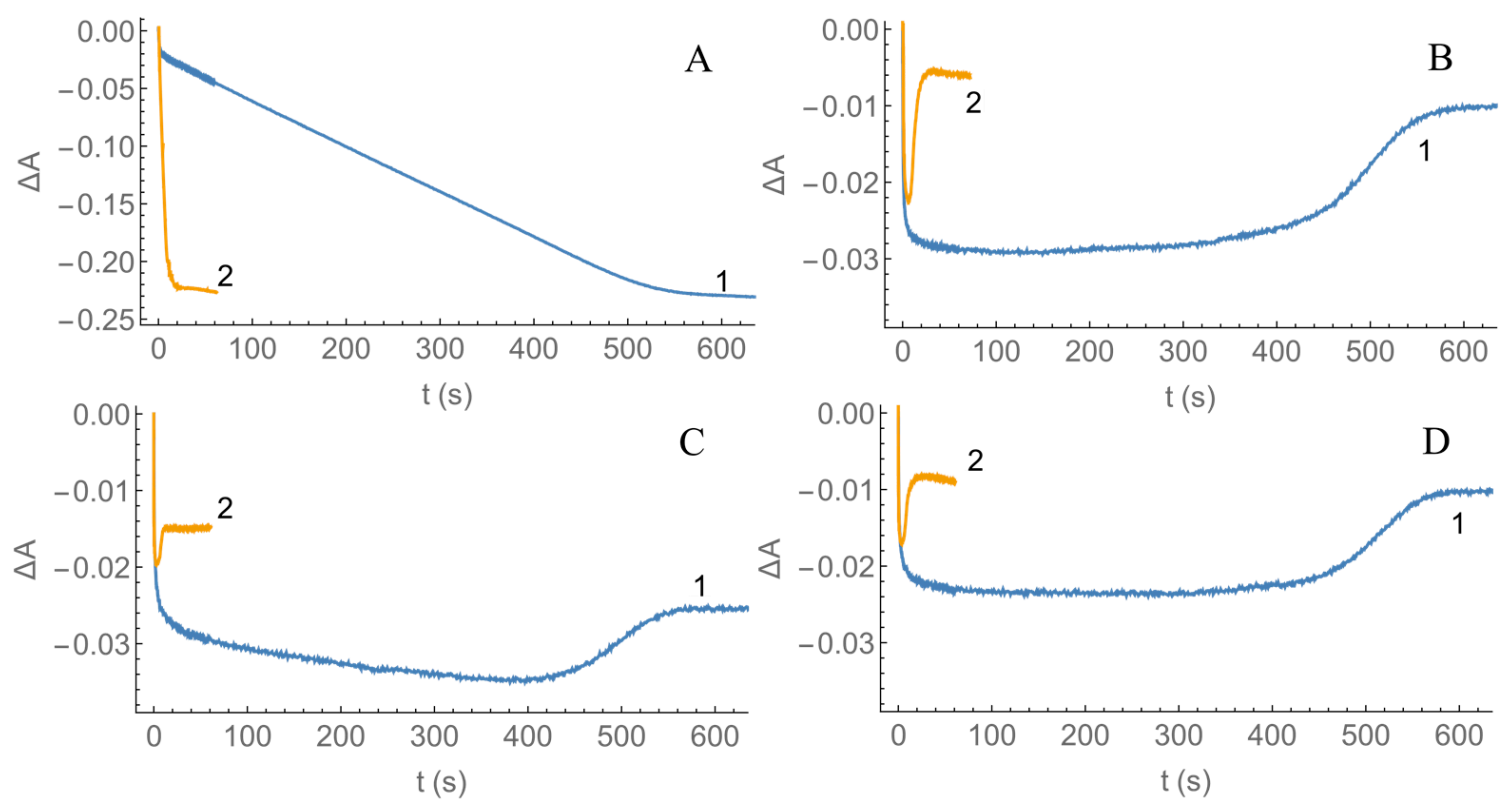

Figure 4. Multiple turnover kinetics of nNOS reduction and reoxidation and NADPH oxidation by $\mathrm{O}_{2}$ (1) or $100 \mu \mathrm{M}$ duroquinone (2) in the absence of CAM. The absorbance changes were followed at $340 \mathrm{~nm}(\mathbf{A}), 485 \mathrm{~nm}(\mathbf{B}), 397 \mathrm{~nm}(\mathbf{C})$, and $436 \mathrm{~nm}$ (D). Concentrations of nNOS and NADPH after mixing, $2.0 \mu \mathrm{M}$ and $30 \mu \mathrm{M}$.

The presence of $\mathrm{CAM}$ and $\mathrm{H}_{4} \mathrm{~B}$ significantly enhanced the turnover of nNOS (Figure $5 \mathrm{~A}$ ). Like in the control experiments (Figure $4 \mathrm{~A}-\mathrm{D}$ ), the addition of duroquinone accelerated the reoxidation of nNOS by one order of magnitude (data not shown). In order to study the full turnover of enzyme and to assess the roles of flavins and heme in the reduction of xenobiotics, all the subsequent experiments were performed in the presence of NOS substrate, arginine. Its addition to the reaction mixture led to an increase of absorbance at $436 \mathrm{~nm}$, indicating the formation of $\mathrm{Fe}^{2+}$-NO complex (Figure 5B).
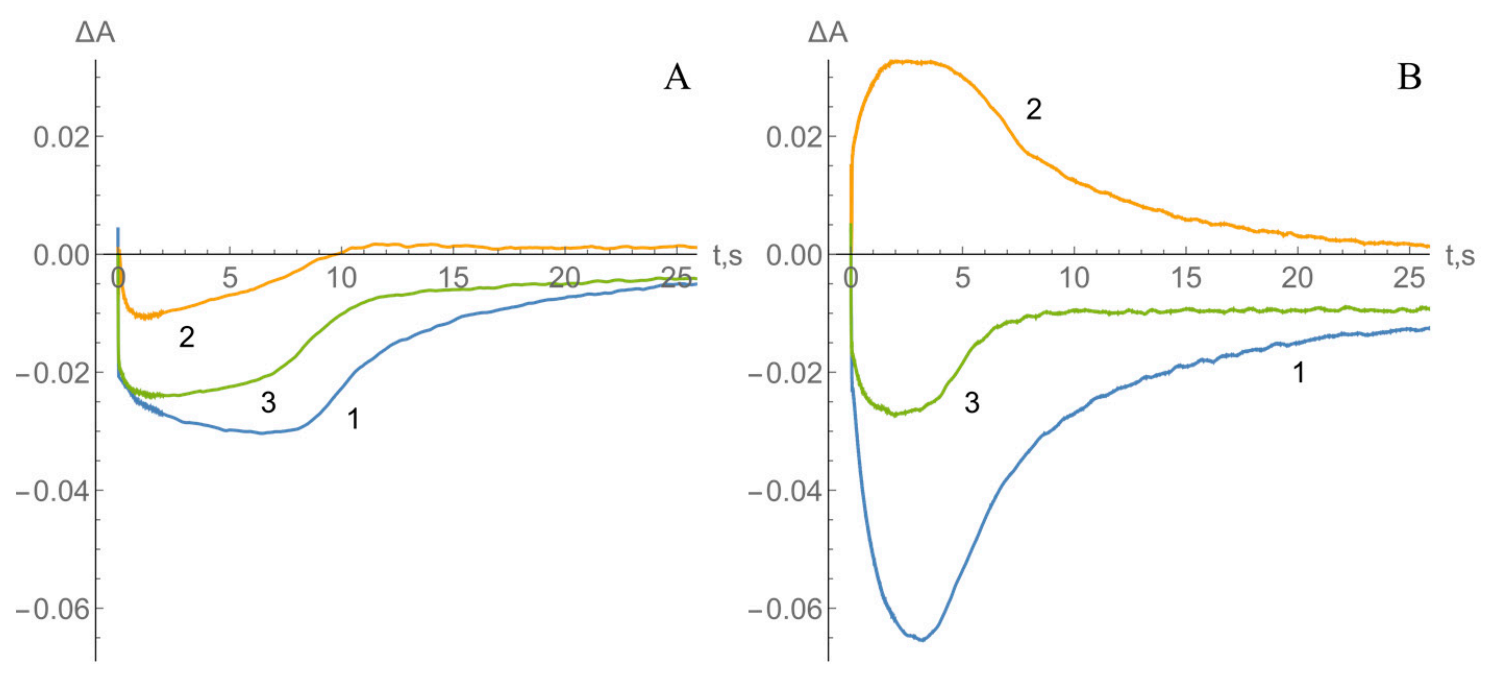

Figure 5. Multiple turnover kinetics of nNOS reduction and reoxidation by $\mathrm{O}_{2}$ in the presence of NADPH, CAM, $\mathrm{H}_{4} \mathrm{~B}$ (A) and NADPH, CAM, $\mathrm{H}_{4} \mathrm{~B}$ and $\mathrm{Arg}(\mathbf{B})$. The absorbance changes were followed at $397 \mathrm{~nm}(1), 436 \mathrm{~nm}$ (2). $485 \mathrm{~nm}$ (3). Concentrations of nNOS and NADPH after mixing, $2.0 \mu \mathrm{M}$ and $30 \mu \mathrm{M}$. 
The analysis of initial absorbance changes of nNOS at $485 \mathrm{~nm}$ (Figure 5B) shows that NADPH reduces flavins biphasically, with $k_{\text {red }}$ of $144.7 \pm 1.5 \mathrm{~s}^{-1}$ and $3.4 \pm 0.2 \mathrm{~s}^{-1}$ for the fast and slow phases with $70 \%$ and $30 \%$ amplitude, respectively. The heme absorbance changes at $397 \mathrm{~nm}$ are characterized by $k_{\text {red }}$ of $67.6 \pm 2.8 \mathrm{~s}^{-1}$ and $1.05 \pm 0.1 \mathrm{~s}^{-1}$, respectively, with their amplitudes of 50\%. The kinetics of $\mathrm{Fe}^{2+}-\mathrm{NO}$ formation at $436 \mathrm{~nm}$ followed after the initial $15 \mathrm{~ms}$ absorbance drop due to flavin reduction, are characterized by $k_{\text {red }}$ of $35.3 \pm 2.4 \mathrm{~s}^{-1}$ and $1.1 \pm 0.1 \mathrm{~s}^{-1}$ with $62 \%$ and $38 \%$ amplitude, respectively. The obtained rate constants are comparable with the ones obtained during reduction of nNOS by excess NADPH under aerobic conditions [40], and with the data of further studies [3]. A second slow phase may be attributed to subsequent processes, e.g., the start of enzyme multiple turnover. The maximal absorbance change at $485 \mathrm{~nm}$ was close to that expected using the value of $\Delta \varepsilon_{485}=12.4 \mathrm{mM}^{-1} \mathrm{~cm}^{-1}$ for the absorbance difference between the oxidized and three-electron-reduced FAD-FMN domain of nNOS [41], i.e., to almost complete formation of three-electron-reduced form. For the estimation of the maximal concentration of $\mathrm{Fe}^{2+}-\mathrm{NO}$ complex, the absorbance difference between $\mathrm{Fe}^{2+}-\mathrm{NO}$ and $\mathrm{Fe}^{3+}$ forms of flavin-free $\mathrm{nNOS}$ heme domain, $\Delta \varepsilon_{436}=34.1 \mathrm{mM}^{-1} \mathrm{~cm}^{-1}$ [13], was corrected for the absorbance difference between oxidized and three-electron-reduced flavin reductase domain, $\Delta \varepsilon_{436}=11.2 \mathrm{mM}^{-1} \mathrm{~cm}^{-1}$ [41]. Applying the obtained value, $\Delta \varepsilon_{436}=22.9 \mathrm{mM}^{-1} \mathrm{~cm}^{-1}$, one may conclude that during the turnover, $67 \%$ of heme exist in $\mathrm{Fe}^{2+}-\mathrm{NO}$ form (Figure $5 \mathrm{~B}$ ), which is comparable with the previously reported value, $81 \%$ [14].

The addition of duroquinone enhances the flavin reoxidation and decreases the amplitude of absorbance changes at $485 \mathrm{~nm}$ (Figure 6A). The kinetics of reoxidation were analyzed by the method of Chance [42] using Equation (4):

$$
k_{\mathrm{ox}}=[\mathrm{NADPH}]_{0} /\left(\left[\mathrm{E}_{\mathrm{red}}\right]_{\max } \times \mathrm{t}_{1 / 2(\text { off })}\right.
$$

where $k_{\mathrm{ox}}$ is the apparent first-order rate constant of enzyme reoxidation, [NADPH] $]_{0}$ is the initial concentration of NADPH, $\left[\mathrm{E}_{\text {red }}\right]_{\max }$ is the maximal concentration of the reduced enzyme formed during the turnover, and $t_{1 / 2 \text { (off) }}$ is the time interval between the formation of the half-maximal amount of $E_{\text {red }}$ and its decay to the half-maximal value.
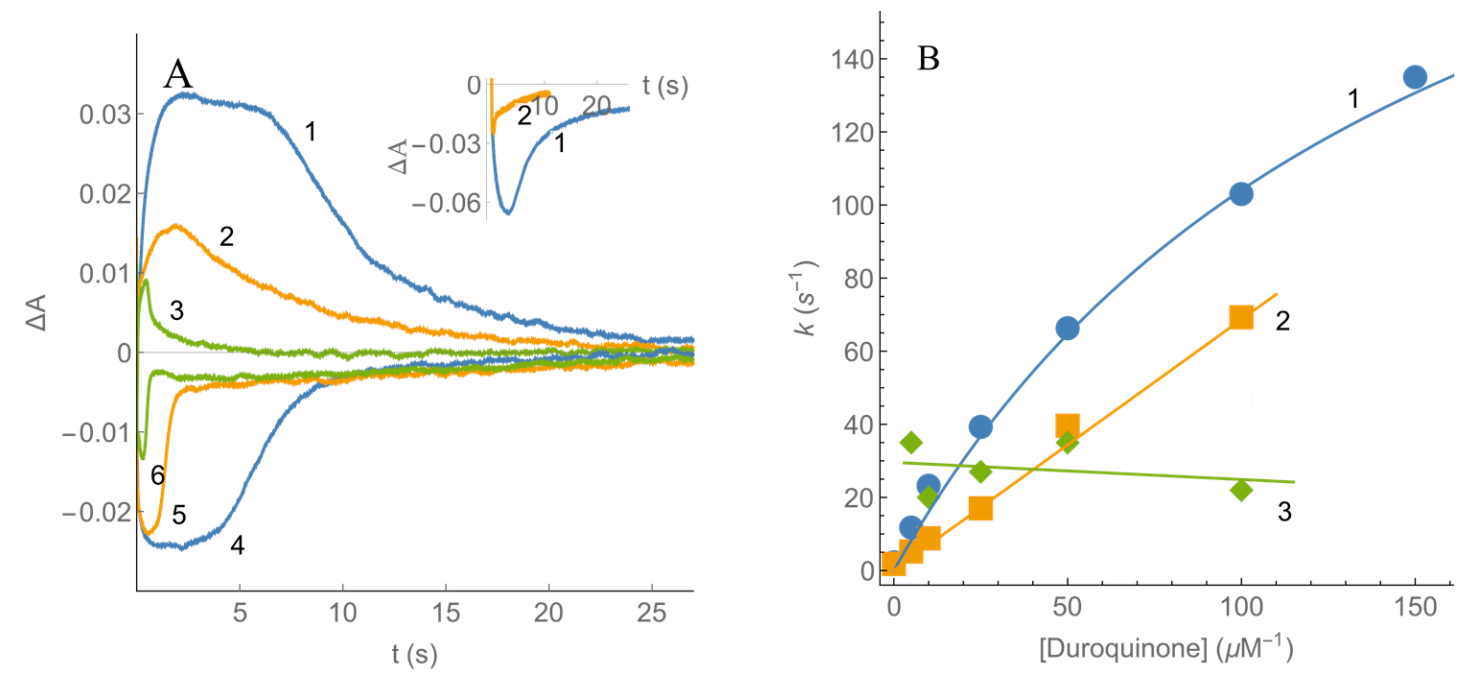

Figure 6. The kinetics of nNOS reduction and reoxidation under multiple turnover conditions in the presence of CAM, $\mathrm{H}_{4} \mathrm{~B}$ and Arg. The concentrations of enzyme and compounds are given after mixing. (A) The spectral changes of $2.0 \mu \mathrm{M}$ nNOS monitored at $436 \mathrm{~nm}$ (1-3) and at $485 \mathrm{~nm}(4-6)$ during the reduction by $30 \mu \mathrm{M}$ NADPH and subsequent reoxidation by $\mathrm{O}_{2}(1,4)$ and by $5.0 \mu \mathrm{M}(2,5)$ or $50(3,6) \mu \mathrm{M}$ duroquinone. The inset shows the kinetics of spectral changes at $397 \mathrm{~nm}$ in the absence (1) and in the presence of $100 \mu \mathrm{M}$ duroquinone (2). (B) Dependence of the apparent first order rate constants of reoxidation of reduced FAD-FMN (1), reoxidation of $\mathrm{Fe}^{2+}-\mathrm{NO}$ complex (2) and formation of $\mathrm{Fe}^{2+}-\mathrm{NO}$ complex (3) on duroquinone concentration. 
The dependence of $k_{\mathrm{ox}}$ on duroquinone concentration (Figure 6B) corrected for $k_{\mathrm{ox}}$ for reaction with $\mathrm{O}_{2}, 2.24 \mathrm{~s}^{-1}$, gives an apparent bimolecular rate constant of $1.7 \pm 0.1 \times 10^{6} \mathrm{M}^{-1} \mathrm{~s}^{-1}$, which is comparable with the steady-state $k_{\text {cat }} / K_{\mathrm{m}}$ for this oxidant (Table 1), and $k_{\mathrm{ox}(\max )}=267 \pm 30 \mathrm{~s}^{-1}$. Thus, using duroquinone as oxidant, the $k_{\text {cat }}$ of the steady-state reaction is limited mainly by the reductive half-reaction. Although duroquinone accelerates $\mathrm{nNOS}$ oxidation followed at $397 \mathrm{~nm}$ with a similar rate (Figure 6A, inset), we further assessed the reoxidation of $\mathrm{Fe}^{2+}-\mathrm{NO}$ complex (Figure 6A), because this is the predominant heme form during the enzyme turnover [14], and its absorbance changes are opposite to those of flavin cofactors. One may note the analysis of this reaction according to Equation (4) is complicated by the branched catalytic cycle of nNOS with the parallel electron flux through several $\mathrm{Fe}^{2+}$ complexes (Scheme 1). After the conditional assumption that the maximal concentration of $\mathrm{Fe}^{2+}-\mathrm{NO}$ during turnover in the presence of $\mathrm{O}_{2}$ is equal to enzyme concentration and after the correction for $k_{\mathrm{ox}}$ of oxygen, $1.8 \mathrm{~s}^{-1}$, an apparent bimolecular rate constant of its reoxidation, $7.4 \pm 0.85 \times 10^{5} \mathrm{M}^{-1} \mathrm{~s}^{-1}$, is obtained (Figure $6 \mathrm{~B}$ ). The addition of $100 \mathrm{U} / \mathrm{mL}$ superoxide dismutase (SOD) did not affect the rate of $\mathrm{Fe}^{2+}-\mathrm{NO}$ reoxidation by duroquinone.

Analogously, the rate constants of $\mathrm{Fe}^{2+}-\mathrm{NO}$ formation during the enzyme reduction by NADPH $\left(k_{\text {red }}\right)$ were calculated according to Equation (5) [42], where $k_{\mathrm{ox}}$ is the rate constant of reoxidation at particular duroquinone concentration, and $[E]_{t}$ is the total enzyme concentration:

$$
k_{\text {red }}=k_{\mathrm{ox}} /\left([\mathrm{E}]_{\mathrm{t}} /\left[\mathrm{E}_{\mathrm{red}}\right]_{\max }-1\right)
$$

Although being scattered (Figure 6B), the obtained values of $k_{\text {red }}$ were comparable with $k_{\text {red }}=35.3 \mathrm{~s}^{-1}$ obtained in the analysis of absorbance rise in the absence of duroquinone. Importantly, an increase in duroquinone concentration affects the value of $k_{\text {red }}$ insignificantly (Figure 6B).

\section{Discussion}

Our study discloses several specific properties of nNOS relevant to the reduction of quinones, nitroaromatic compounds and aromatic $N$-oxides. First, there does not exist a well-defined oxidant specificity except for their reactivity increase with $E^{1}{ }_{7}$, and the difference between two series of compounds, $\mathrm{Q}$ and $\mathrm{ArN} \rightarrow \mathrm{O}$, and $\mathrm{ArNO}_{2}$ (Figure 1A,B). This shows that the model of an "outer-sphere" electron transfer ([28], and references therein) may be also applied for the reactions in the presence of CAM (Figure 1B), i.e., under close to physiological conditions. Importantly, the values of $k_{\text {cat }} / K_{\mathrm{m}}$ of oxidants (Figure 1B) show that in the presence of CAM, nNOS becomes almost as active as rat P-450R [34]. This points to a possibility of their similar responsibility for the oxidative stress-type cytotoxicity of redox cycling xenobiotics in particular types of cells.

In this context, an important problem is the mechanism of the activation of reduction of external oxidants by CAM $[7,8,37,38]$, which, to the best of our knowledge, is far less addressed than its effects on the intraprotein electron transfer [2,3,16,17]. In general, CAM accelerates the transitions between various conformational states of nNOS flavin reductase domain and favors the conformational states with the better FMN accessibility to solvent ([16,17], and references therein), however, it also possibly decreases the $E^{1}{ }_{7}$ of $\mathrm{FMNH} \cdot / \mathrm{FMNH}_{2}$ couple and increases its reactivity [41]. Thus, it is of interest to assess the effect of CAM on the distance of electron transfer in the reduction of quinones by nNOS. According to an "outer-sphere" electron transfer model, the distances of electron transfer $\left(R_{\mathrm{p}}\right)$ between metalloproteins and inorganic complexes may be obtained from the protein electron self-exchange rate constants $\left(k_{11}\right)$ [43]:

$$
R_{\mathrm{p}}(\AA)=6.3-0.35 \ln k_{11}
$$

The application of Equation (6) for the reactions of quinones with single-electron transferring flavoenzymes gives $R_{\mathrm{p}}=3.4-5.0 \AA$ [44], which may be slightly overestimated because of the partial solvent accessibility of flavin cofactors. Thus, these values may be 
useful only for an approximate assessment of the "intrinsic" flavoenzyme reactivity. The $k_{11}$ values of nNOS may be estimated from the data of Figure $1 \mathrm{~A}, \mathrm{~B}$ at $\Delta E^{1}{ }_{7}=0$, where, according to Equation (1), the reaction rate constant $\left(k_{12}\right)$, is equal to $\left(k_{11} \times k_{22}\right)^{1 / 2}$. In this case, the $E^{1}$ of the oxidant should be equal to that of $\mathrm{FMNH}$. $/ \mathrm{FMNH}_{2}$ couple. The results of calculations according to Equation (6) (Appendix A) show that in the presence of CAM, the estimated values of $R_{\mathrm{p}}, 2.8-3.1 \AA$ are lower than in its absence, 3.9-4.7 $\AA$, i.e., a better access to FMN is apparently ensured. Therefore, in spite of a possible decrease of the redox potential of $\mathrm{FMNH}$ - $/ \mathrm{FMNH}_{2}$ by CAM [40], the enhancement of nNOS reactivity is at least partly attributed to an increase in FMN accessibility. Importantly, in this case the $R_{\mathrm{p}}$ values of nNOS become similar to $R_{\mathrm{p}}$ for P-450R, $3.4 \AA$, calculated using the same method [44].

The studies of the ionic strength effects (Figure $2 \mathrm{~A}-\mathrm{C}$ ) provide an additional information on the role of conformational changes of the FMN-binding domain in the reduction of external oxidants. The motions of the FMN-binding domain involve the interaction of negatively charged Glu762 with Arg1229 of the FAD domain, and, in an alternative conformation, the interaction of Glu762, Glu816 and Glu819 with Lys423, Lys620 and Lys660 of the heme domain $[6,39]$. On the other hand, high ionic strength enhanced the reduction of FAD by NADPH and the interflavin electron transfer, and increased flavin fluorescence intensity in CAM-free enzyme [38]. This partly mimicked the effects of CAM, and was interpreted as an induction of enzyme conformation with a better FMN accessibility to solvent. However, the data available so far do not allow to distinguish the role of electrostatic interactions of $\mathrm{nNOS}$ with the charged electron acceptors, and the possible effects of ionic strength on FMN accessibility. The use of $k_{\text {cat }} / K_{\mathrm{m}}$ as a measure of reactivity enabled to demonstrate the existence of the ionic strength-induced conformational change which increases the reactivity of uncharged duroquinone (Figure 2B). Its contribution distorts the expected $\log k_{\text {cat }} / K_{\mathrm{m}}$ vs. $\mu^{1 / 2}$ dependence for the reactions of a negatively charged FMN-binding domain with the charged oxidants, as it is found in reactions of P-450R, where the limiting reactivity was attained at $\mu^{1 / 2}=0.5-0.6 \mathrm{M}^{1 / 2}$ [45]. Instead, the reactivity of negatively charged ferricyanide and $\mathrm{Fe}(\mathrm{EDTA})^{-}$does not reach the limiting value even at $\mu^{1 / 2}=1.0 \mathrm{M}^{1 / 2}$ (Figure $2 \mathrm{C}$ ), apparently because of a general increase in the FMN accessibility at high ionic strength.

Another problem related to the mechanism of reduction of external electron acceptors, is the possible modulation of the reaction rate by repeatedly bound NADP(H). The presteady-state studies of nNOS show that the binding of NADPH or $\mathrm{NADP}^{+}$to the reduced flavin domain inhibits the reduction of external oxidants, evidently inducing a conformational change which restricts the accessibility of FMN [15]. The reaction is not inhibited by $2^{\prime}, 5^{\prime}$-ADP which lacks nicotinamide ring. However, our data (Figure 3A,B) and those of the previous study [31] do not demonstrate different character of inhibition by $\mathrm{NADP}^{+}$and $2^{\prime}, 5^{\prime}$-ADP or $2^{\prime}$-AMP. In our case, $\mathrm{NADP}^{+}$and redox inactive $2^{\prime}, 5^{\prime}$-ADP act as competitive inhibitors to NADPH (Figure $3 \mathrm{~A}$ ), competing for its binding site at the oxidized enzyme form. Their noncompetitive inhibition with respect to duroquinone, and the decrease of $k_{\text {cat(app.) }}$ of reaction in particular (Figure 3B) is most probably caused by an increase of $K_{\mathrm{m}}$ of NADPH at high concentrations of $\mathrm{NADP}^{+}$or $2^{\prime}, 5^{\prime}$-ADP (Figure 3A). In this case, $50 \mu \mathrm{M}$ NADPH is no longer a saturating concentration and does not ensure the maximal reaction rate. Among other possible reasons, the discrepancy between the steadyand presteady-state data may be explained by the participation of four-electron reduced flavin domain of nNOS in the presteady-state experiments [15], whereas the steady-state turnover involves enzyme cycling between single- and three-electron reduced states [7-10].

The data of our study imply that using duroquinone as oxidant, the $k_{\text {cat }}$ of the steadystate reaction is limited mainly by the reductive half-reaction (Figure 6B). Evidently, for most other oxidants, the $k_{\text {cat }}$ is limited by the oxidative half-reaction (Table 1 ). The nature of this phenomenon deserves more thorough studies in the future. On the other hand, according to the previous studies, $N^{\omega}$-nitroarginine that binds at the heme moiety and prevents its reduction by $\mathrm{FMNH}_{2}$ [46], did not inhibit the reduction of nilutamide and CB-1954 by nNOS $[19,20]$. Thus, it was concluded that heme does not participate in the 
reduction of above compounds. However, the multiple turnover experiments show that, in parallel with the reduced FAD-FMN, duroquinone oxidizes the heme of nNOS, in particular its $\mathrm{Fe}^{2+}-\mathrm{NO}$ form (Figure $6 \mathrm{~A}, \mathrm{~B}$ ). In this context one may note that the previous studies $[19,20]$ were performed in the absence of arginine, i.e., under the conditions where $\mathrm{Fe}^{2+}-\mathrm{NO}$ is not formed. The decrease of amplitude and lifetime of absorbance transient at $436 \mathrm{~nm}$ is not caused by the interception of electron flux from $\mathrm{FMNH}_{2}$ to heme, because the rate constant of $\mathrm{Fe}^{2+}-\mathrm{NO}$ formation, $k_{\text {red }}$, insignificantly decreases with an increase in duroquinone concentration (Figure 6B). Another potential mechanism of a decay of $\mathrm{Fe}^{2+}$ $\mathrm{NO}$ is the dissociation of $\mathrm{NO} \cdot$ driven by high rate of formation of peroxynitrite under the action of $\mathrm{O}_{2}{ }^{-\cdot}$ formed during redox cycling of duroquinone [35]. However, the superoxidedriven decomposition of $\mathrm{Fe}^{2+}-\mathrm{NO}$ takes place only after addition of chaotropic agents that decrease the complex stability [35]. Moreover, our findings show that $\mathrm{Fe}^{2+}-\mathrm{NO}$ depletion by duroquinone is insensitive to SOD. On the other hand, $\mathrm{Fe}^{2+}-\mathrm{NO}$ is less reactive than reduced FAD-FMN (Figure 6B), and the rate of its formation, $35.3 \mathrm{~s}^{-1}$, is lower than the rate of reduction of FAD-FMN, $144.7 \mathrm{~s}^{-1}$, or the $k_{\text {cat }}$ of steady-state reaction, $112.2 \mathrm{~s}^{-1}$ (Table 1). This shows that heme may provide only a minor part of electron flux for the reduction of external electron acceptors, and that $\mathrm{FMNH}_{2}$ remains a preferential electron donor. This is in line with an insignificant inhibition of reaction by $\mathrm{NO}_{2}-\mathrm{Arg}$ (Table 1). A similar example is flavohemoglobin, where during the turnover, quinones oxidize the heme much slower than the other redox center, reduced FAD [47]. In this case the azole compounds which bind at the heme moiety do not alter the $k_{\mathrm{cat}} / K_{\mathrm{m}}$ value for oxidant.

Currently, the involvement of heme moiety in reduction of drugs and xenobiotics by NOS is demonstrated only for iNOS-catalyzed reduction of the anticancer prodrug 1,4-bis(aminoalkyl-N-oxide)-anthracene-9,10-dione AQ4N, which is converted into its bis(aminoalkyl)-derivative [48]. The data of this study (Figure 6A,B) expand the variety of structures that may be activated in this way, thus opening a perspective for the design of heme-targeted bioreductively activated agents. The observation of a high reactivity of quinone towards the heme moiety of nNOS may also foster the more detailed studies in the related area, the cytochrome P-450-catalyzed single-electron reduction of quinones, aromatic $N$-oxides and nitrocompounds ([49-51], and references therein). Although these reactions are relevant to the cytotoxicity of the above compounds, their mechanisms are not disclosed at the molecular level because of the use of proteoliposomal preparations but not the isolated enzymes in the studies.

\section{Materials and Methods}

\subsection{Enzymes and Reagents}

Recombinant rat neuronal nitric oxide synthase (nNOS) was prepared as previously described [19]. Its concentration was determined spectrophotometrically according to $\varepsilon_{393}=100 \mathrm{mM}^{-1} \mathrm{~cm}^{-1}$ [52]. The activity of $\mathrm{nNOS}$ determined according to the assay of $\left[{ }^{3} \mathrm{H}\right]$-L-citrulline formation [19], was equal to $280 \pm 50 \mathrm{nmol} \times \mathrm{min}^{-1} \times \mathrm{mg}_{\text {protein }}{ }^{-1}$. 2,4,6-Trinitrotoluene (TNT), 2,4,6-trinitrophenyl-N-methylnitramine (tetryl), 3-amino-1,2,4benzotriazine-1,4-dioxide (tirapazamine) and its 7-substituted derivatives, synthesized as previously $[22,33]$, were a generous gift of Dr. Jonas Šarlauskas (Institute of Biochemistry, Vilnius). 5-(1-Aziridinyl)-2,4-dinitrobenzamide (CB-1954), synthesized as described previously [53], was a generous gift of Dr. Vanda Miškinienė (Institute of Biochemistry, Vilnius). All the synthesized compounds were characterized by their melting points, ${ }^{1} \mathrm{H}-\mathrm{NMR}$ and IR spectra. Cytochrome $c$, NADPH, superoxide dismutase (SOD), calmodulin, $L$-arginine, $N^{\omega}$-nitro-L-arginine, tetrahydrobiopterin, dithiothreitol, benzylviologen, quinones and nitroaromatic compounds were obtained from Sigma-Aldrich (St. Louis, MO, USA) and used as received.

\subsection{Steady-State Kinetic Studies}

All kinetic experiments were carried out spectrophotometrically using a Cary 60 Agilent UV-Vis spectrophotometer (Santa Clara, CA, USA) in 0.1 M Tris-HCl buffer (pH 7.0) 
containing $0.1 \mathrm{M} \mathrm{NaCl}$ and $1.0 \mathrm{mM}$ EDTA at $25^{\circ} \mathrm{C}$. In the experiments with varied ionic strength, different concentrations of $\mathrm{NaCl}$ were added to $0.03 \mathrm{M}$ Tris- $\mathrm{HCl}(\mathrm{pH} 7.0)$ The steady-state parameters of the reactions, namely the catalytic constants $\left(k_{\text {cat }}\right)$ and the bimolecular rate constants (or catalytic efficiency constants, $k_{\text {cat }} / K_{\mathrm{m}}$ ) of the oxidants at fixed concentrations of NADPH $(50 \mu \mathrm{M})$ were obtained by fitting the kinetic data to the parabolic expression using SigmaPlot 2000 (v. 11.0, SPSS Inc., Chicago, IL, USA). They correspond to the reciprocal intercepts and slopes of Lineweaver-Burk plots, [E]/v vs. 1/[oxidant], respectively, where $v$ is the reaction rate and $[E]$ is the enzyme concentration. $k_{\text {cat }}$ represents the number of molecules of NADPH oxidized by a single active center of the enzyme per second under saturating conditions. The concentrations of nNOS used in the experiments were 10-50 nM. The rates of nNOS-catalyzed NADPH oxidation in the presence of quinones, nitroaromatic compounds or tirapazamine derivatives were determined using the value $\Delta \varepsilon_{340}=6.2 \mathrm{mM}^{-1} \mathrm{~cm}^{-1}$. The rates were corrected for the intrinsic NADPH-oxidase activity of the enzyme, $0.1 \mathrm{~s}^{-1}$. The rates of reduction of cytochrome $c$ and ferricyanide were determined using $\Delta \varepsilon_{550}=20 \mathrm{mM}^{-1} \mathrm{~cm}^{-1}$ and $\Delta \varepsilon_{420}=1.0 \mathrm{mM}^{-1} \mathrm{~cm}^{-1}$, respectively. In some experiments, the reaction medium was supplemented by $10 \mu \mathrm{g} / \mathrm{mL}$ calmodulin and $1.0 \mathrm{mM} \mathrm{CaCl}_{2}$, or by CAM-Ca ${ }^{2+}$ and $\mathrm{H}_{4} \mathrm{~B}(5.0 \mu \mathrm{M})$, or by $\mathrm{CAM}^{-\mathrm{Ca}^{2+}}$ and $\mathrm{H}_{4} \mathrm{~B}$ and $L$-arginine $(200 \mu \mathrm{M})$. In this case, the rates were corrected for the intrinsic NADPH-oxidase activity of the enzyme, reaching $1.0-1.7 \mathrm{~s}^{-1}$.

\subsection{Presteady-State Kinetic Studies}

Enzyme rapid kinetic studies were performed using a SX20 stopped-flow spectrophotometer (Applied Photophysics, Leatherhead, UK) under aerobic conditions in $0.1 \mathrm{M}$ Tris- $\mathrm{HCl}(\mathrm{pH} 7.0)$ containing $0.1 \mathrm{M} \mathrm{NaCl}, 3 \%(v / v)$ glycerol at $25^{\circ} \mathrm{C}$. First syringe contained either nNOS $\left(2.0 \mu \mathrm{M}\right.$ after mixing), or nNOS, CAM, $\mathrm{CaCl}_{2}$ and $\mathrm{H}_{4} \mathrm{~B}(2.0 \mu \mathrm{M}, 5.0 \mu \mathrm{M}, 1.0 \mathrm{mM}$ and $5.0 \mu \mathrm{M}$ after mixing, respectively), while second syringe contained NADPH (30 $\mu \mathrm{M}$ after mixing), or NADPH and various concentrations of duroquinone, or NADPH and $L$-arginine (200 $\mu \mathrm{M}$ after mixing), or NADPH, L-arginine and duroquinone. In separate experiments, superoxide dismutase was added to a second syringe. All experiments were performed in triplicate. The kinetic traces at 485, 436 and $397 \mathrm{~nm}$ were analyzed using the accompanying software package by fitting it to single- or double-exponential equations. The multiple turnover data were analyzed by the method of Chance [42].

\section{Conclusions}

Our study shows that under particular conditions, the activity of nNOS in the bioactivation of prooxidant drugs and xenobiotics may be similar to that of P-450R, which is typically regarded as the most important enzyme responsible for their oxidative stress-type cytotoxicity. We characterized several specific properties of nNOS, in particular, the roles of accessibility of FMN and electrostatic interactions, in these reactions. In general, the model of an "outer-sphere" electron transfer which does not predict a pronounced oxidant structure specificity, may be applied for the analysis of currently available data and approximate prediction of reactivity of unexplored quinones, nitroaromatic compounds and aromatic $N$-oxides. However, the demonstration of an involvement of the heme moiety in the reduction of external oxidants may open new perspectives for the design of new specific heme-targeted structures of compounds.

Author Contributions: M.L. performed the kinetic experiments and wrote the draft manuscript, J.-L.B. purified the enzyme, N.C. designed and supervised the experiments and wrote the final manuscript. All authors have read and agreed to the published version of the manuscript.

Funding: This work was supported by the European Social Fund (Measure No. 09.33-LMT-K-712, grant No. DOTSUT-34/09.3.3.-LMT-K712-01-0058/LSS-600000-58) (M.L. and N.Č.).

Institutional Review Board Statement: Not applicable.

Informed Consent Statement: Not applicable. 
Data Availability Statement: The original contributions presented in this study are included in this article. Further inquiries can be directed to the corresponding author.

Conflicts of Interest: The authors declare no conflict of interest. The funders had no role in the design of the study; in the collection, analyses or interpretation of the data; in the writing of the manuscript or in the decision to publish the results.

\section{Appendix A}

There exists some uncertainty with the values of $E^{1}{ }_{7}$ of $\mathrm{FMNH} / \mathrm{FMNH}_{2}$ couple of nNOS determined in different studies even after their adjustment to $\mathrm{pH} 7.0$ (Table A1).

Table A1. Redox potentials of FMNH/FMNH 2 couple $\left(E^{1}\right)$ of nNOS. Their values, adjusted to $\mathrm{pH} 7.0$ assuming that the reduced FMN is doubly protonated [54], are given in parentheses.

\begin{tabular}{ccc}
\hline Conditions & \multicolumn{2}{c}{$\mathbf{E}^{\mathbf{1}(\mathbf{V})}$} \\
\cline { 2 - 3 } & $-\mathbf{C A M}$ & +CAM \\
\hline Flavin reductase domain, pH 7.1 [55] & $-0.274(-0.268)$ & $-0.267(-0.261)$ \\
Holoenzyme, pH 7.0 [54] & -0.220 & $-0.220^{\mathrm{a}}$ \\
Flavin reductase domain, pH 7.5 [56] & & $-0.300(-0.270)$ \\
Flavin reductase domain, pH 7.4 [41] & $-0.199(-0.175)$ & $-0.284(-0.260)$ \\
Flavin reductase domain, pH 7.6 [39] & $-0.276(-0.240)$ & \\
\hline
\end{tabular}

a-The absence of effect of CAM has been reported [54]

For this reason, the highest and lowest $E^{1}{ }_{7}$ values determined in the absence of CAM, $-0.175 \mathrm{~V}$ and $-0.268 \mathrm{~V}$ (Table A1), were used in calculations according to Equation (6). Using the data of Figure $1 \mathrm{~A}$, we obtain $R_{\mathrm{p}}=3.9 \AA\left(\log k_{11}=3.0\right)$, and $R_{\mathrm{p}}=4.7 \AA\left(\log k_{11}=2.0\right)$, respectively. Analogously, using $E^{1}{ }_{7}=-0.220 \mathrm{~V}$ and $E^{1}{ }_{7}=-0.270 \mathrm{~V}$ in the presence of $\mathrm{CAM}$ (Table A1) and the data of Figure $1 \mathrm{~B}$, we obtain $R_{p}=2.8 \AA\left(\log k_{11}=4.4\right)$, and $R_{\mathrm{p}}=3.1 \AA$ $\left(\log k_{11}=4.0\right)$, respectively.

\section{References}

1. Ignarro, L.J.; Freeman, B.A. (Eds.) Nitric Oxide. Biology and Pathobiology, 3rd ed.; Elsevier Inc.: Amsterdam, The Netherlands, 2017; 434p, ISBN 9780128042731.

2. Stuehr, D.J.; Haque, M.M. Nitric oxide synthase enzymology in the 20 years after the Nobel Prize. Br. J. Pharmacol. 2019, 176, 177-188. [CrossRef] [PubMed]

3. Leferink, N.G.H.; Hay, S.; Rigby, S.E.J.; Scrutton, N.S. Towards the free energy landscape for catalysis in mammalian nitric oxide synthases. FEBS J. 2015, 282, 3016-3029. [CrossRef] [PubMed]

4. $\quad$ Wang, M.; Roberts, D.L.; Paschke, R.; Shea, T.M.; Masters, B.S.S.; Kim, J.-J.P. Three-dimensional structure of NADPH-cytochrome P450 reductase: Prototype for FMN- and FAD-containing enzymes. Proc. Natl. Acad. Sci. USA 1997, 94, 8411-8416. [CrossRef]

5. Zhang, J.; Martàsek, P.; Paschke, R.; Shea, T.; Masters, B.S.S.; Kim, J.-J.P. Crystal structure of the FAD/NADPH-binding domain of rat neuronal nitric-oxide synthase: Comparisons with NADPH-cytochrome P450 oxidoreductase. J. Biol. Chem. 2001, 276, 37506-37513. [CrossRef] [PubMed]

6. Garcin, E.D.; Bruns, C.M.; Lloyd, S.J.; Hosfield, D.J.; Tiso, M.; Gachhui, R.; Stuehr, D.J.; Tainer, J.A.; Getzoff, E.D. Structural basis for isozyme-specific regulation of electron transfer in nitric-oxide synthase. J. Biol. Chem. 2004, 279, 37918-37927. [CrossRef] [PubMed]

7. Matsuda, H.; Iyanagi, T. Calmodulin activates intramolecular electron transfer between the two flavins of neuronal nitric oxide synthase flavin domain. Biochim. Biophys. Acta Gen. Subj. 1999, 1473, 345-355. [CrossRef]

8. Matsuda, H.; Kimura, S.; Iyanagi, T. One-electron reduction of quinones by the neuronal nitric-oxide synthase reductase domain. Biochim. Biophys. Acta Bioenerg. 2000, 1459, 106-116. [CrossRef]

9. Guan, Z.-W.; Kamatani, D.; Kimura, S.; Iyanagi, T. Mechanistic studies on the intramolecular one-electron transfer between the two flavins in the human neuronal nitric-oxide synthase and inducible nitric-oxide synthase flavin domains. J. Biol. Chem. 2003, 278, 30859-30868. [CrossRef] [PubMed]

10. Fu, J.; Yamamoto, K.; Guan, Z.-W.; Kimura, S.; Iyanagi, T. Human neuronal nitric oxide synthase can catalyze one-electron reduction of adriamycin: Role of flavin domain. Arch. Biochem. Biophys. 2004, 427, 180-187. [CrossRef] [PubMed]

11. Wei, C.C.; Wang, Z.Q.; Tejero, J.; Yang, Y.P.; Hemann, C.; Hille, R.; Stuehr, D.J. Catalytic reduction of a tetrahydrobiopterin radical within nitric-oxide synthase. J. Biol. Chem. 2008, 283, 11734-11742. [CrossRef] [PubMed]

12. Abu-Soud, H.M.; Wang, J.; Rousseau, D.L.; Fukuto, J.M.; Ignarro, L.J.; Stuehr, D.J. Neuronal nitric oxide synthase self-inactivates by forming a ferrous-nitrosyl complex during aerobic catalysis. J. Biol. Chem. 1995, 270, 22997-23006. [CrossRef] [PubMed] 
13. Tejero, J.; Santolini, J.; Stuehr, D.J. Fast ferrous heme-NO oxidation in nitric oxide synthases. FEBS J. 2009, 276, 4505-4514. [CrossRef]

14. Haque, M.M.; Tejero, J.; Bayachou, M.; Wang, Z.-Q.; Fadlalla, M.; Stuehr, D.J. Thermodynamic characterization of five key kinetic parameters that define neuronal nitric oxide synthase catalysis. FEBS J. 2013, 280, 4439-4453. [CrossRef] [PubMed]

15. Craig, D.H.; Chapman, S.K.; Daff, S. Calmodulin activates electron transfer through neuronal nitric-oxide synthase reductase domain by releasing an NADPH-dependent conformational lock. J. Biol. Chem. 2002, 277, 33987-33994. [CrossRef]

16. He, Y.; Haque, M.M.; Stuehr, D.J.; Lu, H.P. Single-molecule spectroscopy reveals how calmodulin activates NO synthase by controlling its conformational fluctuation dynamics. Proc. Natl. Acad. Sci. USA 2015, 112, 11835-11840. [CrossRef] [PubMed]

17. Campbell, M.G.; Smith, B.C.; Potter, C.S.; Carragher, B.; Marletta, M.A. Molecular architecture of mammalian nitric oxide synthases. Proc. Natl. Acad. Sci. USA 2014, 111, E3614-E3623. [CrossRef]

18. Garner, A.P.; Paine, M.J.I.; Rodriguez-Crespo, I.; Chinje, E.C.; Ortiz De Montellano, P.; Stratford, I.J.; Tew, D.G.; Wolf, C.R. Nitric oxide synthases catalyze the activation of redox cycling and bioreductive anticancer agents. Cancer Res. 1999, 59, 1929-1934. [PubMed]

19. Ask, K.; Dijols, S.; Giroud, C.; Casse, L.; Frapart, Y.M.; Sari, M.A.; Kim, K.S.; Stuehr, D.J.; Mansuy, D.; Camus, P.; et al. Reduction of nilutamide by NO synthases: Implications for the adverse effects of this nitroaromatic antiandrogen drug. Chem. Res. Toxicol. 2003, 16, 1547-1554. [CrossRef] [PubMed]

20. Chandor, A.; Dijols, S.; Ramassamy, B.; Frapart, Y.; Mansuy, D.; Stuehr, D.; Helsby, N.; Boucher, J.-L. Metabolic activation of the antitumor drug 5-(aziridin-1-yl)-2,4-dinitrobenzamide (CB1954) by NO synthases. Chem. Res. Toxicol. 2008, 21, 836-843. [CrossRef]

21. Kumagai, Y.; Kikushima, M.; Nakai, Y.; Shimojo, N.; Kunimoto, M. Neuronal nitric oxide synthase (nNOS) catalyzes one-electron reduction of 2,4,6-trinitrotoluene, resulting in decreased nitric oxide production and increased nNOS gene expression: Implication for oxidative stress. Free Radic. Biol. Med. 2004, 37, 350-357. [CrossRef] [PubMed]

22. Anusevičius, Ž.; Nivinskas, H.; Šarlauskas, J.; Sari, M.-A.; Boucher, J.-L.; Čènas, N. Single-electron reduction of quinone and nitroaromatic xenobiotics by recombinant rat neuronal nitric oxide synthase. Acta Biochim. Pol. 2013, 60, 217-222. [CrossRef]

23. Lopes, M.Â.; Meisel, A.; Carvalho, F.D.; de Lourdes Bastos, M. Neuronal nitric oxide synthase is a key factor in doxorubicininduced toxicity to rat-isolated cortical neurons. Neurotox. Res. 2011, 19, 14-22. [CrossRef] [PubMed]

24. Miller, R.T. Dinitrobenzene-mediated production of peroxynitrite by neuronal nitric oxide synthase. Chem. Res. Toxicol. 2002, 15, 927-934. [CrossRef] [PubMed]

25. Resende, F.F.B.; Titze-de-Almeida, S.S.; Titze-de-Almeida, R. Function of nitric oxide synthase enzyme in temozolomide-induced damage of astrocytic tumor cells. Oncol. Lett. 2018, 15, 4891-4899. [CrossRef] [PubMed]

26. Wang, J.; Guise, C.P.; Dachs, G.U.; Phung, Y.; Hsu, A.H.L.; Lambie, N.K.; Patterson, A.V.; Wilson, W.R. Identification of oneelectron reductases that activate both the hypoxia prodrug SN30000 and diagnostic probe EF5. Biochem. Pharmacol. 2015, 91, 436-446. [CrossRef] [PubMed]

27. Kumagai, Y.; Nakajima, H.; Midorikawa, K.; Homma-Takeda, S.; Shimojo, N. Inhibition of nitric oxide formation by neuronal nitric oxide synthase by quinones: Nitric oxide synthase as a quinone reductase. Chem. Res. Toxicol. 1998, 11, 608-613. [CrossRef] [PubMed]

28. Marcus, R.A.; Sutin, N. Electron transfers in chemistry and biology. Biochim. Biophys. Acta Rev. Bioenerg. 1985, 811, 265-322. [CrossRef]

29. Wardman, P.; Dennis, M.F.; Everett, S.A.; Patel, K.B.; Stratford, M.R.L.; Tracy, M. Radicals from one-electron reduction of nitro compounds, aromatic $\mathrm{N}$-oxides and quinones: The kinetic basis for hypoxia-selective, bioreductive drugs. Biochem. Soc. Symp. 1995, 61, 171-194. [CrossRef]

30. Grampp, G.; Jaenicke, W. ESR-spectroscopic investigation of the parallel electron and proton exchange between quinones and their radicals: Part I. Measurements at 298 K. J. Electroanal. Chem. Interfacial Electrochem. 1987, 229, 297-303. [CrossRef]

31. Wolthers, K.R.; Schimerlik, M.I. Reaction of neuronal nitric-oxide synthase with 2,6-dichloroindolphenol and cytochrome $\mathrm{c}^{3+}$ : Influence of the electron acceptor and binding of $\mathrm{Ca}^{2+}$-activated calmodulin on the kinetic mechanism. Biochemistry 2001, 40, 4722-4737. [CrossRef] [PubMed]

32. Wardman, P. Reduction potentials of one electron couples involving free radicals in aqueous solution. J. Phys. Chem. Ref. Data 1989, 18, 1637-1755. [CrossRef]

33. Hay, M.P.; Gamage, S.A.; Kovacs, M.S.; Pruijn, F.B.; Anderson, R.F.; Patterson, A.V.; Wilson, W.R.; Brown, J.M.; Denny, W.A. Structure-activity relationships of 1,2,4-benzotriazine 1,4-dioxides as hypoxia-selective analogues of tirapazamine. J. Med. Chem. 2003, 46, 169-182. [CrossRef] [PubMed]

34. Nemeikaitè-Čènienè, A.; Šarlauskas, J.; Jonušienè, V.; Marozienè, A.; Misevičienè, L.; Yantsevich, A.V.; Čènas, N. Kinetics of flavoenzyme-catalyzed reduction of tirapazamine derivatives: Implications for their prooxidant cytotoxicity. Int. J. Mol. Sci. 2019, 20, 4602. [CrossRef]

35. Nishimura, J.S.; Narayanasami, R.; Miller, R.T.; Roman, L.J.; Panda, S.; Masters, B.S.S. The stimulatory effects of Hofmeister ions on the activities of neuronal nitric-oxide synthase. J. Biol. Chem. 1999, 274, 5399-5406. [CrossRef] [PubMed]

36. Panda, K.; Haque, M.M.; Garcin-Hosfield, E.D.; Durra, D.; Getzoff, E.D.; Stuehr, D.J. Surface charge interactions of the FMN module govern catalysis by nitric-oxide synthase. J. Biol. Chem. 2006, 281, 36819-36827. [CrossRef]

37. Welland, A.; Garnaud, P.E.; Kitamura, M.; Miles, C.S.; Daff, S. Importance of the domain-domain interface to the catalytic action of the NO synthase reductase domain. Biochemistry 2008, 47, 9771-9780. [CrossRef] [PubMed] 
38. Welland, A.; Daff, S. Conformation-dependent hydride transfer in neuronal nitric oxide synthase reductase domain. FEBS J. 2010, 277, 3833-3834. [CrossRef] [PubMed]

39. Haque, M.M.; Tejero, J.; Bayachou, M.; Kenney, C.T.; Stuehr, D.J. A cross-domain charge interaction governs the activity of NO synthase. J. Biol. Chem. 2018, 293, 4545-4554. [CrossRef] [PubMed]

40. Miller, R.T.; Martásek, P.; Omura, T.; Siler Masters, B.S. Rapid kinetic studies of electron transfer in the three isoforms of nitric oxide synthase. Biochem. Biophys. Res. Commun. 1999, 265, 184-188. [CrossRef]

41. Dunford, A.J.; Rigby, S.E.J.; Hay, S.; Munro, A.W.; Scrutton, N.S. Conformational and thermodynamic control of electron transfer in neuronal nitric oxide synthase. Biochemistry 2007, 46, 5018-5029. [CrossRef]

42. Chance, B. A simple relationship for a calculation of the "on" velocity constant in enzyme reactions. Arch. Biochem. Biophys. 1957, 71, 130-136. [CrossRef]

43. Mauk, A.G.; Scott, R.A.; Gray, H.B. Distances of electron transfer to and from metalloprotein redox sites in reactions with inorganic complexes. J. Am. Chem. Soc. 1980, 102, 4360-4363. [CrossRef]

44. Lesanavičius, M.; Aliverti, A.; Šarlauskas, J.; Čènas, N. Reactions of Plasmodium falciparum ferredoxin:NADP+ oxidoreductase with redox cycling xenobiotics: A mechanistic study. Int. J. Mol. Sci. 2020, 21, 3234. [CrossRef]

45. Čènas, N.; Anusevičius, Ž.; Bironaitè, D.; Bachmanova, G.I.; Archakov, A.I.; Ollinger, K. The electron-transfer reactions of NADPH-cytochrome P450 reductase with nonphysiological oxidants. Arch. Biochem. Biophys. 1994, 315, 400-406. [CrossRef]

46. Abu-Soud, H.M.; Feldman, P.L.; Clark, P.; Stuehr, D.J. Electron transfer in the nitric-oxide synthases. Characterization of L-arginine analogs that block heme iron reduction. J. Biol. Chem. 1994, 269, 32318-32326. [CrossRef]

47. Moussaoui, M.; Misevičienè, L.; Anusevičius, Ž.; Marozienè, A.; Lederer, F.; Baciou, L.; Čènas, N. Quinones and nitroaromatic compounds as subversive substrates of Staphylococcus aureus flavohemoglobin. Free Radic. Biol. Med. 2018, 123, 107-115. [CrossRef] [PubMed]

48. Nishida, C.R.; Ortiz de Montellano, P.R. Reductive heme-dependent activation of the N-oxide prodrug AQ4N by nitric oxide synthase. J. Med. Chem. 2008, 51, 5118-5120. [CrossRef] [PubMed]

49. Lavaggi, M.L.; Cabrera, M.; González, M.; Cerecetto, H. Differential enzymatic reductions governing the differential hypoxiaselective cytotoxicities of phenazine 5,10-dioxides. Chem. Res. Toxicol. 2008, 21, 1900-1906. [CrossRef] [PubMed]

50. Goeptar, A.R.; Scheerens, H.; Vermeulen, N.P.E. Oxygen and xenobiotic reductase activities of cytochrome P450. Crit. Rev. Toxicol. 1995, 25, 25-65. [CrossRef] [PubMed]

51. Pochapsky, T.C.; Wong, N.; Zhuang, Y.; Futcher, J.; Pandelia, M.-E.; Teitz, D.R.; Colthart, A.M. NADH reduction of nitroaromatics as a probe for residual ferric form high-spin in a cytochrome P450. Biochim. Biophys. Acta Proteins Proteom. 2018, 1866, 126-133. [CrossRef] [PubMed]

52. Voegtle, H.L.; Sono, M.; Adak, S.; Pond, A.E.; Tomita, T.; Perera, R.; Goodin, D.B.; Ikeda-Saito, M.; Stuehr, D.J.; Dawson, J.H. Spectroscopic characterization of five- and six-coordinate ferrous-NO heme complexes. evidence for heme Fe-proximal cysteinate bond cleavage in the ferrous-NO adducts of the Trp-409Tyr/Phe proximal environment mutants of neuronal nitric oxide synthase. Biochemistry 2003, 42, 2475-2484. [CrossRef] [PubMed]

53. Miškinienè, V.; Sergedienè, E.; Nemeikaitè, A.; Segura-Aguilar, J.; Čènas, N. Role of redox cycling and activation by DT-diaphorase in the cytotoxicity of 5-(aziridin-1-yl)-2,4-dinitrobenzamide (CB-1954) and its analogs. Cancer Lett. 1999, 146, 217-222. [CrossRef]

54. Gao, Y.T.; Smith, S.M.E.; Weinberg, J.B.; Montgomery, H.J.; Newman, E.; Guillemette, J.G.; Ghosh, D.K.; Roman, L.J.; Martasek, P.; Salerno, J.C. Thermodynamics of oxidation-reduction reactions in mammalian nitric-oxide synthase isoforms. J. Biol. Chem. 2004, 279, 18759-18766. [CrossRef] [PubMed]

55. Noble, M.A.; Munro, A.W.; Rivers, S.L.; Robledo, L.; Daff, S.N.; Yellowlees, L.J.; Shimizu, T.; Sagami, I.; Guillemette, J.G.; Chapman, S.K. Potentiometric analysis of the flavin cofactors of neuronal nitric oxide synthase. Biochemistry 1999, 38, 16413-16418. [CrossRef] [PubMed]

56. Garnaud, P.E.; Koetsier, M.; Ost, T.W.B.; Daff, S. Redox properties of the isolated flavin mononucleotide- and flavin adenine dinucleotide-binding domains of neuronal nitric oxide synthase. Biochemistry 2004, 43, 11035-11044. [CrossRef] [PubMed] 